Berkala Ilmu Perpustakaan dan Informasi, Vol. 15, No. 1, Juni 2019, Hal. 21-33 DOI: 10.22146/bip.34628

ISSN 1693-7740 (Print), ISSN 2477-0361 (Online)

Tersedia online di https://jurnal.ugm.ac.id/bip

\title{
Bibliobattle sebagai strategi promosi: studi kasus di Perpustakaan Kementerian Sosial Republik Indonesia
}

\author{
Galih Panuntun, Margareta Aulia Rachman ${ }^{1}$ \\ ${ }^{1}$ Program Studi Ilmu Perpustakaan dan Informasi, Fakultas Ilmu Pengetahuan Budaya, Universitas Indonesia \\ e-mail:margareta.aulia@ui.ac.id
}

Naskah diterima: 10 April 2018, direvisi: 11 Agustus 2018, disetujui: 24 November 2018

\begin{abstract}
ABSTRAK
Pendahuluan. Penelitian ini membahas mengenai Bibliobattle sebagai strategi promosi yang dilakukan oleh Perpustakaan Kementerian Sosial Republik Indonesia. Bibliobattle merupakan kegiatan yang unik karena memiliki bentuk seperti bedah buku namun dikemas dalam bentuk permainan yang dipertandingkan. Penelitian mengenai promosi perpustakaan menggunakan Bibliobattle di perpustakaan khusus kementrian belum pernah dilakukan.

Metode Penelitian. Pendekatan penelitian yang digunakan adalah kualitatif dengan metode studi kasus. Metode pengumpulan data yang digunakan adalah dengan observasi, wawancara dan studi dokumen. Informan penelitian dipilih berdasarkan metode purpossive sampling dimana terdapat kriteria dalam pemilihannya.

Data Analisis. Data dianalisis dengan melakukan reduksi data, intepretasi data kemudian data dianalisis dan dikakukan penarikan kesimpulan.

Hasil dan Pembahasan. Strategi promosi menggunakan Bibliobattle pada pelaksanaannya berfokus pada promosi melalui hubungan publik. Selain itu, untuk mempromosikan kegiatan Bibliobattle, pustakawan memiliki fokus pada alat promosi berupa iklan, penjualan personal, dan pemasaran langsung dan digital.

Kesimpulan dan Saran. Hasil dari penelitian ini menunjukkan strategi promosi menggunakan Bibliobattle pada kenyatanyaan tidak hanya mempromosikan eksistensi perpustakaan, namun koleksi perpustakaan itu sendiri. Selama ini fokus kegiatan promosi di perpustakaan khusus masih sebatas promosi adanya unit perpustakaan.
\end{abstract}

Kata kunci: Bibliobattle; Strategi Promosi; Perpustakaan Kementrian Sosial RI; Promosi Perpustakaan

\section{ABSTRACT}

Introduction. This study discusses about Bibliobattle as a promotion strategy conducted by the Library of the Ministry of Social Affairs of the Republic of Indonesia. Bibliobattle is a unique activity because it has a book-like shape but is packed in game form. Research on library promotion using Bibliobattle in a special library of ministries has never been done.

Data Collection Method. The research approach used is qualitative with case study method. The data collection method used is by observation, interview and document study. The research informants were chosen based on purposive sampling method where there were criteria in the selection.

Analysis Data. Data were analyzed by data reduction, interpretation, analyzed and conducted withdrawal conclusion.

Result and Discussions. The promotion strategy using Bibliobattle on its implementation focuses on promotion through public relations. In addition, to promote Bibliobattle's activities, librarians focus on promotional tools of advertising, personal selling, and direct and digital marketing.

Conclutions. The results of this study show that promotional strategies using Bibliobattle in fact not only promote the existence of libraries, but the library's own collection. During this time the focus of promotional activities in the special library is still limited to the promotion of the library unit.

Keywords: Bibliobattle; Promotion Strategy; Library of the Ministry of Social Affairs; Library Promotion 


\section{A. PENDAHULUAN}

Promosi merupakan kegiatan yang harus dilakukan oleh semua institusi salah satunya perpustakaan khusus. Salah satu cara promosi di perpustakaan adalah dengan Bibliobattle. Li dan Mao (2015) dalam artikelnya yang berjudul " $A$ Book Review Game in Japan - Bibliobattle and Its Promotion Potential in China" menyatakan kegiatan Bibliobattle secara umum di Jepang dari kurun waktu 2010 sampai 2013 memperoleh peningkatan yang sangat tinggi. Melihat potensi perkembangan itu, Li dan Mao mengelompokkan beberapa kelompok yang dapat menjadi media potensial untuk kegiatan Bibliobattle di Cina. Salah satu kelompok yang disorot adalah kelompok yang berkaitan dengan buku, seperti toko buku dan perpustakaan. Menurutnya, perpustakaan mengalami masalah di tengah banyaknya buku elektronik dan dengan masalah yang ada, perpustakaan perlu memperoleh kembali popularitasnya. Selanjutnya, perpustakaan dapat membuat kegiatan ini yang ditunjukkan untuk pengunjung yang akan meminjam buku.

Berdasarkan observasi di Perpustakaan Kementerian Sosial Republik Indonesia (yang selanjutnya disebut Perpustakaan Kemensos RI) melakukan berbagai kegiatan promosi dengan Bibliobattle. Bibliobattle merupakan kegiatan yang unik karena memiliki bentuk seperti bedah buku namun dikemas dalam bentuk permainan yang dipertandingkan. Dalam kegiatan ini, beberapa buku dilombakan untuk menjadi buku terbaik melalui presentasi isi buku yang dilakukan oleh presenter (yang merupakan istilah dalam Bibliobattle bagi peserta yang melakukan presentasi buku) yang telah membaca dan memahami buku tersebut. Perpustakaan Kemensos RI telah melaksanakan kegiatan Bibliobattle selama dua kali sejak tahun 2016. Hal ini menarik untuk dikaji bagaimana strategi promosi perpustakaan melalui kegiatan Bibliobattle di Perpustakaan Kemensos RI, dampaknya terhadap kunjungan perpustakaan setelah melakukan kegiatan promosi melalui Bibliobattle, serta hambatan yang dihadapi dalam kegiatan ini. Tujuan penelitian ini untuk menganalisis strategi promosi dan dampak yang dilakukan
Perpustakaan Kemensos RI melalui kegiatan Bibliobattle serta mendeskripsikan hambatan perpustakaan dalam melaksanakan kegiatan Bibliobattle. Taniguchi \& Kawakami (2009) mengusulkan Bibliobattle sebagai kerangka interaksi sosial. Kerangka ini diterapkan untuk membangun skema manajemen komunitas dalam organisasi sosial yang melibatkan pekerja yang memiliki pengetahuan, misalnya dalam sebuah perusahaan, laboratorium, atau perguruan tinggi. Pekerja yang memiliki pengetahuan dimaknai sebagai individu yang dihargai karena kemampuan mereka untuk menafsirkan informasi dan menciptakan ide-ide baru. Bibliobattle dirancang untuk membantu orang menemukan dan berbagi informasi menarik. Sebagai tambahan, Bibliobattle diharapkan dapat meningkatkan keterampilan presentasi peserta dan untuk membantu mengatur dan mengaktifkan komunikasi dalam suatu organisasi. Pada penelitian ini, Bibliobattle diterapkan pada jenis perpustakaan khusus. Penelitian tentang strategi promosi menggunakan Bibliobattle di Perpustakaan Khusus belum pernah dilakukan di Indonesia. Penelitian yang sudah ada dilakukan oleh $\mathrm{Li}$ (2015) dengan judul A Book Review Game in Japan-Bibliobattle and its Promotion Potential in China. Hasilnya menunjukkan bibliobattle adalah desain dan platform, dan tujuan utamanya untuk mencapai dan mempromosikan komunikasi interpersonal. Hal ini membuat penelitian ini menjadi menarik dan bermanfaat sebagai salah satu media interaksi dalam berkomunikasi di dalam organisasi perpustakaan.

\section{B. TINJAUAN PUSTAKA}

Pemasaran dalam definisi yang mudah berarti membuat hubungan yang baik dengan pelanggan dan membangun hubungan yang erat dengan pengguna guna mendapatkan nilai sebagai timbal balik dari pengguna (Kotler \& Armstrong, 2016). Lebih lanjut, pemasaran merupakan kegiatan sosial dan manajerial yang berkaitan dengan individu atau organisasi mengenai apa yang dibutuhkannya dan bersedia melakukan pertukaran dan pembuatan nilai dengan lainnya. Selain itu, Vasileiou dan 
Rowley (2011) dalam jurnalnya yang berjudul "Marketing and promotion of e-books in academic libraries" menyebutkan untuk melakukan promosi terdapat peralatan yang digunakan. Kata peralatan yang dimaksudkan bukanlah peralatan seperti alat-alat pada umumnya, namun berupa fasilitas perpustakaan seperti situs web perpustakaan, sesi literasi informasi, OPAC, pengantar (pengenalan terhadap perpustakaan), instruksi individual, dan surat elektronik. Dapat dikatakan bahwa layanan yang diberikan oleh perpustakaan akan mempengaruhi perpustakaan dalam melakukan promosinya.

Pemasaran pada perpustakaan tidaklah berbeda jauh dengan pemasaran pada umumnya. Kotler dan Armstrong (2016) menyatakan promotion mix yang dilakukan oleh sebuah perusahaan merupakan penggabungan unsur iklan, promosi penjualan, penjualan pribadi, hubungan publik, serta pemasaran secara langsung dan digital untuk menarik pelanggan, mengajak pelanggan menyampaikan nilainya, dan membuat hubungan dengan pelanggan. Setelah mengetahui promotion mix, perusahaan perlu menyusun rancangan promotion mix. Solomon, Marshall, dan Stuart (2012) menyatakan pesan pada promotion mix harus dapat mencakup empat objek, yaitu bagaimana pesan tersebut mendapatkan perhatian, memperoleh ketertarikan, menimbulkan keinginan, dan menghasilkan aksi untuk memilikinya atau dapat juga disebut AIDA. Lewis dalam Li (2013) menyatakan AIDA merupakan deskripsi dari kegiatan yang terjadi pada pengguna ketika tertarik pada sebuah iklan yang kita keluarkan. Jika dijabarkan, AIDA merupakan singkatan dari Attention, Interest, Desire, dan Action. Familmaleki (2015) menyatakan alat promosi (promotion mix) dapat membantu perusahaan untuk membuat pengguna mencapai tahap Attention dan Interest.

\section{METODE PENELITIAN}

Penelitian ini menggunakan pendekatan kualitatif. Metode penelitian yang digunakan dalam penelitian ini adalah studi kasus. Pengumpulan data yang digunakan adalah melalui observasi partisipatif, wawancara, dan studi dokumen. Jenis wawancara yang dipilih adalah wawancara tak berstruktur. Sedangkan pada studi dokumen data yang diambil mengenai jumlah kunjungan di tahun sebelum melaksanakan kegiatan Bibliobattle dan tahun saat melaksanakan kegiatan Bibliobattle dan jumlah koleksi.

Informan yang dipilih dalam penelitian ini berjumlah lima orang menggunakan purposive sampling. Adapun kriteria informan adalah pegawai yang terlibat dengan kegiatan Bibliobattle, pegawai yang terlibat dalam kegiatan sebagai pengisi acara, pegawai yang berfungsi sebagai pengambil kebijakan atau bertanggung jawab pada kegiatan Bibliobattle. Tabel 1 merupakan tabel informan penelitian.

Tahapan analisis data adalah proses mencari dan menyusun secara sistematis data yang diperoleh dari tahapan observasi dan wawancara. Proses analisis data melibatkan pemaknaan dari teks dan data gambar yang telah diperoleh dari pengamatan di lapangan. Dalam penelitian ini, analisis data dilakukan dengan beberapa tahap, yaitu triangulasi, interpretasi, dan penarikan kesimpulan.

\section{HASIL DAN PEMBAHASAN \\ 1. Bibliobattle di Perpustakaan Kemensos RI}

Kegiatan Bibliobattle di Perpustakaan Kemensos dimulai sejak tahun 2016 saat staf perpustakaan diundang ke perpustakaan Japan Foundation untuk berbagi informasi mengenai kegiatan Bibliobattle.

"Ee.. awalnya mbak Lina kan seminggu kan sering bersama teman-teman pustakawannya ya kumpul, nah pas lagi ke perpustakaan kementerian mana atau ke Japan Foundation dia itu diundang. ternyata dia nonton di youtube itu, ternyata di Jepang ada namanya Bibliobattle." (Sarah)

"Dia pernah cerita kalo misalnya dia pernah mengikuti kegiatan perpustakaan di mana gitu, ada acara Bibliobattle ini. Terus dia cerita ke teman-teman sini kalo misalnya dia punya ide untuk membuat acara serupa di sini, gitu." (Tania) 
Pada pertemuan tersebut, staf pustakawan dan para undangan diberikan demonstrasi kegiatan Bibliobattle. Taniguchi and Kawakami (2009), sebagai pengembang Bibliobattle, menyatakan, Bibliobattle adalah sarana untuk berbagi informasi melalui buku di mana para peserta berkumpul untuk mengenalkan buku yang telah dibaca sebelumnya, berinteraksi, dan membagikan rekaman videonya melalui media internet. Setelah mempelajari kegiatan ini, staf perpustakaan tersebut merasa tertarik untuk melaksanakan kegiatan Bibliobattle di Perpustakaan Kemensos RI. Menurut tambahan dari Sarah, sebelum merumuskan kegiatan, Lina mencari terlebih dahulu informasi tambahan di internet melalui video pelaksanaannya. Hal ini seperti yang disampaikan oleh Potter and Kendrick (2012) yang menyatakan sebelum membuat perencanaan pemasaran kita harus mengetahui ambisi (tujuan perpustakaan) dan menempatkan orang yang profesional untuk mengurusnya. Tidak hanya itu, Rukmana dan Komariah (2017) pada penelitiannya mengenai Strategi Pemasaran Toko Buku (Studi Kasus di Toko Buku Jatinangor, Sumedang), menyatakan dari konsep strategi marketing, faktor people atau pengelola perpustakaan menjadi faktor kuat di antara faktor lainnya. Pengelola perpustakaan dituntut memahami buku yang dijual, mahir berkomunikasi dengan pelanggan dan lancar menggunakan teknologi, mereka harus menjalin kerja sama dengan penerbit dan pelanggan.

Bibliobattle pada awalnya masih mengikuti peraturan yang asli dari pembuatnya. Pada pelaksanaan Bibliobattle di Kementerian Sosial terdapat beberapa penyesuaian jika dibandingkan dengan pelaksanaannya di Jepang.

\footnotetext{
"Tapi kalo kita liat di Jepang kaku banget ya kelihatannya kalau di youtube itu, nah bisa kita kembangkan di sini sesuai dengan apa namanya, karakter orang Indonesia seperti apa. Sebaiknya sih fleksibel sesuai dengan ee... apa namanya... budaya Indonesia, karakter Indonesia lah." (Ari)
}

Dari kutipan wawancara tersebut, setelah melihat video pada youtube mengenai kegiatan Bibliobattle, Ari menyatakan perlu adanya penyesuaian dalam pelaksanaan kegiatan yang diterapkan di Kementerian Sosial. Hal ini bertujuan untuk menghilangkan suasana tegang seperti yang terlihat di video yang ditontonnya. Peraturan yang ada juga sebaiknya disesuaikan dengan karakter masyarakat Indonesia. Salah satu contoh yang penyesuaian yang dilakukan di Perpustakaan Kemensos RI adalah waktu yang diberikan untuk diskusi buku. Dalam peraturan aslinya, waktu untuk mendiskusikan isi buku dengan peserta yang hadir selama dua menit. Namun, pada pelaksanaannya waktu dapat sampai sepuluh menit (lebih fleksibel) karena diskusi dapat menarik minat peserta yang datang untuk menanyakan isi lebih lanjut dari buku itu yang memungkinkan peserta itu menginginkan untuk membacanya. Selain dari peraturan, Bibliobattle juga memiliki sisi lain yang menjadi sifat unik kegiatan ini.

"ada sisi refreshnya juga yg menarik, kayaknya kalo sekedar bedah buku aja kan orang mikirnya udah berat gitu kan" (Lina)

Konsep yang digunakan dalam Bibliobattle memiliki konsep yang cukup berbeda dari sebuah bedah buku. Konsep Bibliobattle bersifat ringan dan menarik. Konsep ini memungkinkan Bibliobattle dapat mengangkat daya baca pemirsa yang menghadirinya. Bibliobattle memiliki sisi permainan yang memberikan semacam hiburan. Hal inilah yang memberikan nilai menarik dari konsep ini. Menurutnya juga, konsep ini dapat digunakan juga untuk mempromosikan koleksi yang terdapat pada Perpustakaan Kemensos RI.

Pelaksanaan permainan Bibliobattle dibagi menjadi tiga sesi. Pada tiap sesi, dua orang presenter akan mempresentasikan buku yang dibacanya selama lima menit untuk masingmasing presenter. Buku yang dipresentasikan dijelaskan mengenai informasi bibliografi dari buku (judul, pengarang, penerbit, tahun terbit, dan halaman buku), alasan pemilihan buku, mempresentasikan isi ringkas buku beserta bagian-bagian yang dianggap menarik, dan hal- 
hal yang berkaitan dengan isi buku. Setelah presenter melakukan presentasi, buku tersebut akan didiskusikan bersama peserta yang hadir selama sepuluh menit bagi tiap-tiap presenter. Proses diskusi dilakukan dengan cara menyampaikan pertanyaan sebanyak tiga sampai lima pertanyaan. Setelah melakukan presentasi dan diskusi, pada setiap sesi di antara dua buku akan langsung diadakan voting (pemilihan) buku yang terbaik. Dari ketiga sesi yang telah dilaksanakan, akan diperoleh tiga buku terbaik dari masing-masing sesi. Ketiga buku tersebut kemudian akan dipilih kembali untuk memperoleh buku terbaik dan sekaligus juga menentukan tiga besar buku terbaik. Buku terbaik yang terpilih akan menjadi buku juara dan diberi nama Champion Book of The Day (atau dalam bahasa Jepangnya Champ-bon).

Perpustakaan Kemensos RI telah melaksanakan kegiatan Bibliobattle selama dua kali. Pertama dilakukan pada tahun 2016 dengan tema "Show Your Brain Power". Bibliobattle kedua dilaksanakan pada April 2017 dengan tema "Women in Literature". Dalam setiap pelaksanaannya, jumlah peserta dan presenter yang berpartisipasi dalam Bibliobattle berjumlah sama, yaitu 6 presenter dan 50 peserta. Jumlah presenter Bibliobattle dipilih enam orang karena mengikuti peraturan yang ada. Jumlah peserta yang berpartisipasi dibatasi 50 peserta karena ruangan perpustakaan yang terbilang cukup kecil. Bagi presenter, perpustakaan tidak menentukan dari unit mana saja yang dapat menjadi presenter, namun presenter dapat dari unit mana saja karena pendaftaran untuk presenter dibuka secara umum di lingkungan Kementerian Sosial RI. Beda halnya dengan peserta, karena peserta yang menghadiri ditentukan bergiliran dari tiap unit sesuai yang ditunjuk dari pihak perpustakaan.

\section{Bibliobattle sebagai Strategi Promosi}

Konsep bauran pemasaran erat kaitannya dengan konsep 4P. Jika dijabarkan, keempat konsep itu adalah Product (produk), Place (lokasi), Price (biaya), dan Promotion (promosi). Umumnya saat melakukan kegiatan pemasaran, komponen bauran pemasaran akan tersusun baik yang direncanakan untuk menyusun maupun tidak menyusunnya. Termasuk juga dengan kegiatan pemasaran di Perpustakaan Kemensos RI.

a. Product (Produk)

Ketika melakukan promosi, maka ada produk yang ditampilkan. Produk yang ditampilkan pada promosi adalah sesuatu benda atau jasa yang dapat membuat orang lain merasa tertarik untuk menggunakannya atau memiliki. Perpustakaan Kemensos RI dalam menjalankan promosinya juga menawarkan produk yang tersedia, seperti dinyatakan dalam kutipan wawancara berikut.

"Produk yang ditawarkan ya layanan ya koleksi.”(Lina)

Dari petikan wawancara tersebut, maka produk yang menjadi bahan untuk dipromosikan adalah layanan beserta koleksi Perpustakaan Kemensos RI. pernyataan tersebut berkaitan dengan konsep yang dinyatakan Kotler dan Armstrong (2016) yaitu produk adalah barang/jasa yang ditawarkan oleh sebuah lembaga. Berbagai layanan yang ditawarkan oleh Perpustakaan Kemensos RI, seperti yang sudah disebutkan sebelumnya, dapat menarik peserta dan presenter kegiatan Bibliobattle yang datang ke perpustakaan untuk mengerjakan tugasnya ataupun untuk rekreasi. Layanan yang disediakan Perpustakaan Kemensos RI juga dapat menunjang pengunjung dalam melakukan pekerjaannya. Koleksi yang ditawarkan juga umumnya berupa koleksi di bidang sosial. Namun, koleksi di bidang sosial yang ditawarkan bukan hanya koleksi yang bersifat teoritis ilmu sosial, ada juga koleksi yang berupa bahan bacaan ringan berkaitan dengan permasalahan sosial yang dapat menjadi referensi tambahan sekaligus sarana rekreasi.

\section{b. Place(Lokasi)}

Perpustakaan Kemensos RI dalam melakukan kegiatan promosi tentunya juga berkaitan dengan lokasi. Lokasi dapat menjadi tantangan dalam kegiatan promosi, karena lokasi dapat menentukan minat seseorang untuk 
mendatangi tempat itu. Menangani masalah lokasi, pihak perpustakaan juga melakukan cara agar lokasi perpustakaan dapat diketahui, seperti yang dinyatakan dalam kutipan wawancara berikut:

"Kita kasih pengumuman di grup whatsapp apa, jadi tau tuh akhirnya datang ke sini. Sama pameran di internal kita di gedung kita yang orang-orang suka kunjungi waktu itu barengan pameran"(Lina)

Kutipan wawancara tersebut berkaitan dengan pernyataan Kotler dan Armstrong (2016) yaitu lokasi berkaitan juga dengan aktivitas agar layanannya dapat tersedia untuk target pasarnya. Patil \& Pradhan (2014) menyatakan jika lokasi bukan hanya tempat perpustakaan itu. Lokasi juga termasuk area letak informasi yang dicari oleh pengguna. Aktivitas yang dilakukan perpustakaan untuk mencapai pengguna dengan tidak membawa koleksinya ke berbagai tempat. Namun, perpustakaan ini mencoba untuk mempromosikan perpustakaannya melalui pemanfaatan media sosial dan pemanfaatan kegiatan pameran yang sedang berlangsung. Selain memanfaatkan promosi dan kegiatan pameran, perpustakaan juga melakukan promosi melalui media tercetak seperti penempatan $x$-banner di lantai delapan untuk menunjukkan lokasi perpustakaan serta memberikan tanda petunjuk perpustakaan di lantai 1 setelah memasuki lobi. Dalam kaitannya dengan Bibliobattle, perpustakaan juga melakukan promosi melalui pemanfaatan media sosial dan melalui selebaran yang dipasang di tiap-tiap lift untuk menarik minat karyawan mengikuti kegiatan ini.

\section{c. Price (Biaya)}

Untuk memperoleh sebuah produk atau layanan, setiap orang perlu mengeluarkan sesuatu, seperti misalkan uang. Namun, ada kalanya untuk memperoleh barang atau jasa tidak perlu mengeluarkan uang (tanpa biaya/gratis). Di Perpustakaan Kemensos RI, untuk memperoleh layanan ada hal yang perlu dilakukan, seperti pada kutipan wawancara berikut:
"Ya paling yang pertamajadi anggota dulu, kunjungan ke sini dulu”.(Lina)

Kutipan wawancara di atas menjelaskan hal yang perlu dilakukan untuk memperoleh buku dan layanan yang diinginkan adalah dengan menjadi anggota perpustakaan ini terlebih dahulu. Dari kutipan wawancara tersebut juga dapat disimpulkan, bahwa biaya yang dikeluarkan untuk menjadi anggota adalah gratis. Mengikuti pernyataan Kotler dan Armstrong (2016), biaya dapat diartikan sebagai sejumlah uang yang dikeluarkan untuk memperoleh barang atau jasa. Untuk biaya yang dikeluarkan agar memperoleh layanan perpustakaan adalah gratis. Pelaksanaan Bibliobattle memerlukan dana untuk kegiatan operasional sehingga acara menjadi lancar.

"Dana ya biasalah kalo anggaran. Tapi ya gimana kita bisanya aja sih, jangan jadi hambatan, justru malah jadi lebih kreatif." (Lina)

Dari kutipan wawancara tersebut, secara tersirat dapat dipahami dana yang digunakan untuk operasional terbatas. Namun, dengan keterbatasan dana yang dimiliki untuk melakukan promosi, perpustakaan dapat mencari jalan lain untuk melakukan promosi

\section{d. Promotion(Promosi)}

Agar sebuah barang atau jasa dapat diketahui oleh setiap orang, perlu adanya sebuah pengenalan. Kegiatan pengenalan ini dapat disebut juga promosi. Perpustakaan Kemensos RI juga telah melakukan berbagai cara promosi agar layanan yang ditawarkan beserta koleksinya dapat sampai ke setiap orang, terutama karyawan di lingkungan Kementerian Sosial RI. Seperti yang dijabarkan dalam kutipan wawancara berikut.

"Promosinya itu ee.. ya macem-macem ya sejak saya udah disini udah di perpustakaan itu udah mulai dari pembuatan leaflet, pembatas buku, lalu banner yang ada di lift, lalu ada pameran yang ada di dalam dan di luar kemensos" (Lina) 
Berdasarkan hasil pengamatan promosi kegiatan Bibliobattle telah dilakukan melalui pemanfaatan media sosial dan dengan memasang selebaran di tiap lift. Hal ini berkaitan dengan konsep promosi yang merupakan cara penyampaian pesan yang dilakukan terhadap produk yang ditawarkan dengan tujuan mempengaruhi target untuk memilikinya (Kotler \& Armstrong, 2016). Konteksnya dengan kutipan wawancara tersebut, penyampaian pesan yang telah dilakukan melalui pembuatan leaflet, pembatas buku, banner, beserta pameran. Ketika melakukan kegiatan promosi, perpustakaan secara tidak langsung melakukan promosi terhadap koleksi. Promosi layanan yang telah dilakukan melalui pembuatan leaflet, website, dan pameran. Selain itu, layanan juga dipromosikan secara langsung pada kegiatan Bibliobattle.

Itu kan udah termasuk semua dalam kegiatan Bibliobattle (promosi layanan). Yang satunya dijelaskan ada apa aja layanan, termasuk udah include. (Lina)

Susunan acara kegiatan Bibliobattle, telah disediakan waktu selama lima menit untuk melakukan promosi perpustakaan. Dari hasil pengamatan, promosi yang disampaikan berupa berbagai layanan yang ditawarkan perpustakaan serta layanan koleksi dan terbitan berkala yang dimiliki dan dilanggan perpustakaan. Promosi yang dilakukan perpustakaan bersifat sekilas namun dapat menjelaskan dengan jelas layanan yang disediakan. Hal ini berkaitan dengan konsep Toterdell (2005) yang menyatakan untuk melakukan promosi sebaiknya melakukan dengan sederhana namun memperhatikan lingkup formal.

\section{Promosi Bibliobattle di Perpustakaan Kemensos RI}

Kotler dan Armstrong (2016) menyatakan promotion mix yang dilakukan oleh sebuah perusahaan merupakan penggabungan unsur iklan, promosi penjualan, penjualan pribadi, hubungan publik, serta pemasaran secara langsung dan digital untuk menarik pelanggan, mengajak pelanggan menyampaikan nilainya, dan membuat hubungan dengan pelanggan. Kelima unsur-unsur tadi jika dijabarkan menjadi berikut:

a. Iklan

Perpustakaan Kemensos RI dalam melakukan promosi kegiatan Bibliobattle membuat selebaran berukuran A4 yang dipasang di lift Kementerian Sosial RI. Selebaran itu berisikan ajakan untuk mengikuti kegiatan Bibliobattle sebagai presenter. Selebaran tersebut dapat diidentifikasikan sebagai sebuah iklan. Mengikuti pendapat Kotler dan Armstrong (2016), iklan merupakan presentasi dari ide, barang, atau layanan dalam bentuk promosi tidak baku yang dapat diidentifikasi sponsor. Selain itu, penggunaan iklan dapat juga membantu Perpustakaan Kemensos RI untuk mengajak setiap orang mengikuti Bibliobattle sebagai presenter.

\section{b. Penjualan Personal}

Selain melalui iklan, Perpustakaan Kemensos RI juga mempromosikan kegiatan Bibliobattle melalui pendekatan langsung dari pustakawan terhadap target pasar. Promosi Bibliobattle dilakukan melalui pembicaraan mulut ke mulut yang dapat menarik setiap orang untuk mendatangi acara. Penyebaran informasi mengenai kegiatan ini dilakukan oleh rekanrekan pustakawan sampai ke orang lainnya. Promosi dilakukan dengan cara customer to customer. Kedua pernyataan tersebut juga berkaitan dengan unsur bauran promosi Penjualan Personal oleh Kotler dan Armstrong (2016) karena promosi dilakukan dengan cara interaksi dan hubungan interpersonal.

\section{c. Pemasaran Langsung dan Digital}

Perpustakaan Kemensos RI dalam melakukan promosi juga memanfaatkan pemasaran melalui digital. Perpustakaan Kemensos RI menggunakan media sosial WhatsApp untuk menyebarkan informasi mengenai adanya kegiatan Bibliobattle sekaligus untuk mengajak pembacanya mengikuti kegiatan ini. Dengan pemanfaatan media ini, Perpustakaan Kemensos RI dapat juga berinteraksi dengan target pasar tanpa 
harus bertemu langsung. Iklan pada pemasaran langsung dan digital ini dapat dikaitkan dengan kegiatan yang dilakukan Perpustakaan Kemensos RI saat melakukan pengiriman pesan mengenai kegiatan Bibliobattle pada media sosial yang ada seperti menggunakan Facebook. Media sosial merupakan sarana yang paling mudah dan murah dalam menyebarkan informasi. Rachman (2017) menyatakan proses penyebaran informasi tidak hanya terjadi karena teknologi yang memungkinkan informasi untuk disebarkan tetapi juga karena budaya yang ada di media sosial untuk menyebarkan kembali informasi yang diperoleh.

\section{d. Hubungan Publik}

Untuk memperoleh citra yang baik, perpustakaan perlu untuk melakukan kegiatan yang berkaitan dengan masyarakat atau komunitas sekitar. Perpustakaan telah melakukan berbagai kegiatan yang berkaitan dengan masyarakat seperti halnya menghadiri pameran. Selain menghadiri pameran, Perpustakaan Kemensos RI membuat kegiatan yang dapat menarik minat komunitas seperti Bibliobattle. Menurut Kotler dan Armstrong (2016) promosi melalui kegiatan seperti Bibliobattle berkaitan terhadap unsur hubungan publik. Dengan demikian, Perpustakaan Kemensos RI telah membangun hubungan publik membangun hubungan baik yang sekaligus membangun citra dengan salah satunya membuat sebuah kegiatan berupa Bibliobattle. Proses promosi dilakukan dengan cara pustakawan memberitahukan kepada beberapa rekannya dan kemudian rekannya memberitahukan kembali ke rekan lainnya. Hal ini dapat diketahui dari metode penyebaran informasi yang menjadi fokusnya adalah melalui komunikasi mulut-ke-mulut. Hal ini sejalan dengan penelitian Nurhidayah (2015) bahwa komunikasi interpersonal secara langsung dan melalui media merupakan hal yang penting untuk meningkatkan loyalitas pengguna perpustakaan.

\section{Segmentasi Pasar dan Sasaran Pemasaran}

Segmentasi pasar memiliki kaitan dengan sasaran pemasaran. Jika dijelaskan secara ringkas, segmentasi pasar merupakan pembagian/pengelompokan tipe pengguna. Sedangkan sasaran pemasaran berupa pemilihan target yang akan menjadi objek untuk dipromosikan berdasarkan pengelompokan pada segmentasi pasar. Perpustakaan Kemensos RI dalam mempromosikan perpustakaan beserta layanannya secara tidak langsung juga telah melakukan pengelompokan sesuai segmentasi pasar dan sasaran pemasaran. Seperti yang dijelaskan pada kutipan wawancara berikut.

"kan awalnya ee.. ini kan baru, takutnya orang belum ada yang ngerti, jadi terus promosi juga, jadi internal kita dulu lah, nah humas dulu." (Sarah)

"Target kita kan tiap tahun berbeda ya, tahun kemarin kita di lingkungan sekjen, tahun ini yang kemarin itu bulan april itu campuran sekjen sama rehsos (direktorat rehabilitasi sosial). Jadi kita promosikan per unit salah satu, ganti-gantian setiap tahun gitu kan, karena tempat terbatas kan."(Lina)

Secara tersirat, berdasarkan kutipan wawancara tersebut segmentasi pasar yang dibuat oleh perpustakaan berdasarkan unit-unit kerja yang ada di dalam Kementerian Sosial RI. Dapat dijabarkan pula pembagian segmentasi pasar yang dilakukan sebagai berikut: Sekretariat Jenderal, Direktorat Jenderal Perlindungan dan Jaminan Sosial, Direktorat Jenderal Rehabilitasi Sosial, Direktorat Jenderal Pemberdayaan Sosial, Direktorat Jenderal Penanganan Fakir Miskin, Inspektorat Jenderal, Badan Pendidikan Penelitian dan Penyuluhan Sosial, Staf Ahli Bidang Perubahan dan Dinamika Sosial, Staf Ahli Bidang Teknologi Kesejahteraan Sosial, dan Staf Ahli Bidang Aksesibilitas Sosial. Untuk pelaksanaan Bibliobattle yang pertama kali (tahun 2016), sasaran pemasaran yang dipilih Sekretariat Jenderal. 
Alasan pemilihan Sekretariat Jenderal sebagai sasaran pemasaran karena kegiatan ini baru pertama kali dilaksanakan di Kementerian Sosial RI. Maka dari itu, untuk memulai kegiatan ini dipilihlah segmen pasar yang terdekat dahulu karena perpustakaan berada di bawah Sekretariat Jenderal. Pada penyelenggaraan tahun 2017 yang menjadi sasaran pemasaran yakni Direktorat Rehabilitasi Sosial untuk menjadi pemirsa dalam kegiatan Bibliobattle. Untuk presenter, promosinya yang dilakukan cenderung lebih luas karena berfokus menarik minat dari keseluruhan unit yang ada untuk mengikuti kegiatan ini. Hal ini berkaitan dengan teori Kotler dan Armstrong (2016) yang menjelaskan mengenai segmentasi pasar, di mana segmentasi pasar sebagai kegiatan pengelompokan pasar besar menjadi kelompok kecil. Berdasarkan pengamatan juga, pada Bibliobattle kedua saat mengundang Direktorat Rehabilitasi Sosial, buku yang diadu juga berkaitan dengan rehabilitasi sosial. Konsep segmentasi ini mengarah ke dalam segmentasi bisnis di mana pembagian kegiatan promosinya berdasarkan divisi (unit) yang terdapat dalam bisnis perusahaan itu (Kotler dan Armstrong 2016).

\section{Pemanfaatan Perpustakaan Setelah kegiatan Bibliobattle}

Setiap kegiatan promosi diharapkan mendapatkan hasil yang baik, terutama bagi lembaga yang melaksanakan. Manfaat yang diterima dapat berupa dampak baik maupun dampak buruk. Manfaat bagi Perpustakaan Kemensos RI, promosi ini memiliki fokus untuk meningkatkan jumlah kunjungan.

"Dampaknya yaitu, e...jumlah kunjungannya bertambah, terus yang pasti pegawai jadi yang belum pernah ke perpustakaan jadi tau "oh ada perpustakaan di sini”, ada yang baru tau, ada loh, jangan salah, namanya juga ga suka baca ya. Makanya, itu bagus banget buat promosi, kan yang belum pernah ikut Bibliobattle jadi pengen ikutan dong, kan merasa tertantang gitu kan."(Lina)
"Itu gara-gara Bibliobattle jumlah kunjungan yang datangin perpus jadi nambah." (Sarah)

Dari kutipan wawancara tersebut, setelah melaksanakan kegiatan Bibliobattle manfaat yang dirasakan adalah peningkatan dalam kunjungan. Hal lain yang dirasakan adalah perpustakaan dapat menunjukkan keberadaannya ke berbagai karyawan, termasuk pada karyawan yang belum mengetahui adanya perpustakaan dalam lingkungan Kementerian Sosial RI. Dari hasil pengamatan, koleksi yang menjadi bahan untuk Bibliobattle dicari oleh pengunjung yang datang. Ketika datang, pengunjung tersebut akan mencari terlebih dahulu koleksi yang diinginkannya lalu kemudian bertanya. Ketika buku yang diinginkannya (buku yang menjadi bahan Bibliobattle) tidak ada, pengunjung itu mencari buku yang berkaitan untuk dipinjam. Hal ini menunjukkan kegiatan Bibliobattle tidak hanya dapat mempromosikan koleksi yang dipakai untuk kegiatan ini, namun koleksi dengan subjek yang berkaitan juga secara tidak langsung turut dipromosikan.

Peningkatan jumlah kunjungan ini juga didukung dengan data statistik kunjungan tahunan. Statistik ini diperoleh dari buku tamu yang perlu diisi oleh setiap pengunjung yang akan masuk ke ruang perpustakaan. Namun, temuan peneliti di lapangan menunjukkan bahwa tidak setiap pengunjung yang datang ke perpustakaan mengisi buku tamu. Mereka biasa langsung masuk menuju ruang koleksi ataupun ruang baca.

Pada tahun 2015, sebelum kegiatan Bibliobattle dimulai, jumlah kunjungan perpustakaan total berjumlah 828 kunjungan. Tahun 2016 saat kegiatan Bibliobattle dimulai, jumlah kunjungan perpustakaan menjadi 955 kunjungan dalam satu tahun. Jika kita memperhatikan jumlah kunjungan yang dilakukan oleh karyawan Kementerian Sosial RI, terjadi peningkatan sebanyak 198 kunjungan. Jumlah kunjungan ini juga belum termasuk karyawan yang mengunjungi perpustakaan tanpa mengisi buku tamu. Hal ini dapat dikaitkan dengan tujuan kegiatan 
Bibliobattle yaitu untuk meningkatkan jumlah kunjungan perpustakaan oleh karyawan di lingkungan Kementerian Sosial RI. Program menarik yang diadakan di perpustakaan sudah terbukti dapat meningkatkan jumlah kunjungan pengguna ke perpustakaan. Hal ini dibuktikan oleh penelitian Albayyinah dan Rachman (2017), dimana Program Lomba Dongeng Anak telah berhasil untuk menarik perhatian warga Depok untuk mengetahui keberadaan layanan anak di Perpustakaan Umum Kota Depok, hal tersebut terbukti dengan melonjaknya peserta lomba sehingga untuk pelaksanaannya pada tahun 2017 ini jumlahnya harus dibatasi.

Kegiatan Bibliobattle merupakan kegiatan yang menggunakan buku sebagai bahan untuk permainan. Di Perpustakaan Kemensos RI, buku yang menjadi bahan permainan merupakan buku koleksi perpustakaan. Buku yang menjadi bahan untuk kegiatan ini adalah buku yang memiliki nilai menarik untuk dibahas. Tidak hanya pada jumlah kunjungan, kegiatan Bibliobattle ini juga memiliki dampak terhadap jumlah peminjaman koleksi Perpustakaan Kemensos RI. Untuk lebih lanjut dapat dilihat pada Tabel 4.

Dari data sirkulasi tahun 2015, (sebelum dilaksanakannya kegiatan Bibliobattle) dapat dijabarkan selama satu tahun transaksi peminjaman sebanyak 198 koleksi. Dari data statistik sirkulasi tahun 2016 (tahun saat pelaksanaan kegiatan Bibliobattle dimulai), jumlah peminjaman yang terjadi sebanyak 482 transaksi. Angka transaksi yang dialami Perpustakaan Kemensos RI mengalami peningkatan yang tinggi jika dibandingkan dengan tahun lalu. Menjelang akhir tahun pada bulan Oktober dan November (bulan dimulainya kegiatan Bibliobattle) mengalami peningkatan transaksi pada peminjaman dan pengembalian.

Selain peningkatan kunjungan dan peminjaman, terdapat sebuah temuan yang terjadi pasca Bibliobattle. Kegiatan Bibliobattle memiliki pesan yang disampaikan di dalamnya. Seperti terlihat pada kutipan wawancara berikut

"Karena tahu sendiri kan kita tuh bangsa yang tidak suka baca, jadi kita harus cari cara yang menyenangkan yang tidak bikin boring, jadi ada sisi refreshnya juga yg menarik, kayaknya kalo sekedar bedah buku aja kan orang mikirnya udah berat gitu kan, terlalu ilmiah atau apa. ”(Lina)

Pustakawan melihat mengenai permasalahan yang ada pada masyarakat umumnya. Untuk mengubah sikap orang, pustakawan mengadakan kegiatan yang bersifat ringan. Kegiatan ini membuat presenternya "harus membaca" untuk mengetahui buku yang dibawanya agar dapat dipresentasikan dengan baik. Tidak cukup dengan membuat orang untuk membaca, pustakawan Perpustakaan Kemensos RI juga memiliki pesan di dalam kegiatan ini. Seperti yang dijelaskan pada kutipan wawancara berikut.

Pertama kita bikin orang suka dulu dengan suasana perpustakaan, dengan layanan kita. Dibikin senang dulu lho. (Lina)

Pustakawan melalui kegiatan Bibliobattle juga telah menunjukkan lokasi perpustakan beserta dengan suasana yang ada. Suasana perpustakaan dibuat senyaman mungkin agar setiap orang yang berkunjung merasa betah dan ingin untuk terus datang ke perpustakaan. Pesan ini juga menunjukkan bahwa perpustakaan bukan hanya sekedar tempat untuk meminjam buku. Namun, perpustakaan dapat juga menjadi tempat untuk berekspresi. Dengan adanya pesan yang disampaikan ini, pustakawan juga mengubah persepsi pengguna mengenai perpustakaan.

\section{Kendala Pada Pelaksanaan Bibliobattle}

Setiap kegiatan ada kalanya memiliki hambatan yang muncul, baik yang telah terjadi saat perancangan kegiatan maupun yang muncul secara tiba-tiba. Seperti yang disampaikan oleh Khanchandani \& Hasan (2016) bahwa perpustakaan akan melalui periode pergeseran paradigma. Untuk menyelamatkan perpustakaan dari devaluasi dan mempertahankan keberlanjutan kegiatan, pemasaran sumber daya perpustakaan, layanan dan produk adalah satu-satunya solusi. Untuk 
itu, pustakawan harus mampu mengatasi kendala dalam pelaksanaan program di perpustakaan. Kegiatan Bibliobattle juga memiliki kendala dalam pelaksanaannya. Kendala pertama yang dihadapi adalah sempitnya ruangan. Hal ini juga dirasakan peneliti saat membantu penyusunan kursi karena ada beberapa barang yang harus dipindahkan terlebih dahulu. Namun, pemilihan ruangan ini tetap menjadi prioritas mengingat yang ingin dipromosikan utamanya adalah perpustakaan. Menghadapi kendala tersebut, pihak Perpustakaan Kemensos RI mengatasinya dengan membagi pemirsanya ke dalam berbagai kelompok dalam sebuah unit. Kendala kedua adalah publikasi untuk mengundang menjadi presenter. Untuk mengundang presenter, awalnya pustakawan berencana menggunakan layar TV yang terdapat di lobby dan tiap lantai. Biasanya, TV ini menampilkan kegiatan yang telah dilakukan oleh Kementerian Sosial RI. Saat ingin menampilkan video untuk promosi kegiatan ini, ternyata mengurusi peminjamannya terbilang rumit karena layar TV ini bukan dari Biro Humas yang menanganinya (tidak seperti pada layar TV di lobby). Mengatasi hal itu, pihak perpustakaan memiliki cara kreatif lainnya yaitu dengan meletakkan selebaran ajakan menjadi presenter Bibliobattle di dalam lift. Selebaran itu dibuat dengan desain yang dapat menarik perhatian dan diletakkan di dinding lift sehingga dapat menarik perhatian setiap orang yang naik lift.

\section{E. KESIMPULAN}

Strategi promosi menggunakan Bibliobattle pada kenyataannya tidak hanya mempromosikan eksistensi perpustakaan, namun koleksi perpustakaan itu sendiri. Selama ini fokus kegiatan promosi di perpustakaan khusus masih sebatas promosi adanya unit perpustakaan. Pelaksanaan Bibliobattle di Perpustakaan Kemensos RI menunjukkan perpustakaan berfokus melakukan promosi melalui hubungan publik. Selain itu, untuk mempromosikan kegiatan Bibliobattle, pustakawan memiliki fokus pada alat promosi berupa iklan, penjualan personal, dan pemasaran langsung dan digital. Manfaat yang diperoleh Perpustakaan Kemensos RI sejak Bibliobattle adalah suasana perpustakaan yang menjadi lebih hidup dikarenakan mulai datangnya orang untuk sekadar berkunjung sampai mengerjakan tugas di perpustakaan. Manfaat lainnya yang dirasakan Perpustakaan Kemensos RI adalah keterpakaiannya koleksi yang dimiliki. Hal ini dikarenakan pada kegiatan Bibliobattle, koleksi yang dimiliki perpustakaan dapat menjadi bahan untuk permainan. Selain itu, keberhasilan promosi menggunakan Bibliobattle dapat meningkatkan peran perpustakaan bagi institusi.

\section{DAFTAR PUSTAKA}

Albayyinah, D,. \& Rachman, M A,. (2017). Layanan anak di Perpustakaan Umum Kota Depok. Proceeding of 2nd International Young Scholars Symposium of Humanities and Arts (INUSHARTS 2017). August 28302017 , Faculty of Humanities Universitas Indonesia, Indonesia, pp. 127-144. https://inusharts.ui.ac.id/wpcontent/ uploads/sites/31/2018/01/Proceeding INU SHARTS17 FINAL-2018JAN24.pdf

Familmaleki, M., Aghighi, A., \& Hamidi, K. (2015). Analyzing the impact of promotion mix on consumer's purchase decision. Advanced Social Humanities and Management, 2 (1), 72-81.

Khanchandani, V.,\& Hasan, N., (2016). Marketing of library resources, services and products: a case study of IIT Delhi. DESIDOC Journal of Library \& Information Technology, 36 (3), 158-163.

Nurhidayah, R,. (2015). Evaluasi strategi pemasaran dalam upaya membangun loyalitas pengguna di perpustakaan UIN Sunan Kalijaga Yogyakarta ditinjau dari pendekatan customer relationship management. Berkala Ilmu Perpustakaan dan Informasi, 11 (1), 24-44.

Li, H., \& Mao, J. (2015). A book review game in Japan - bibliobattle and its promotion potential in China. Management \& Engineering, 7 (1) 14-19.

Li, J., \& Yu, H. (2013). An innovative marketing model based on AIDA: a case from e-bank campus-marketing by China Construction Bank. iBusiness, 5(3B), 47-51. 
Kotler, P., Armstrong, \& Gary. (2016). Principles of marketing. England: Pearson.

Patil, S., \& Pradhan, P. (2014). Library promotion practices and marketing of library services: a role of library professionals. Procedia - Social and Behavioral Sciences, 249-254.

Potter, N., \& Kendrick,T. (2012). Marketing your library. American Libraries, 43(11/12), 50-52

Rachman, M A. (2017). Pola penyebaran informasi oleh remaja pada masyarakat urban di media sosial: kajian budaya informasi. Seminar Nasional Budaya Urban Kajian Budaya Urban di Indonesia dalam Perspektif Ilmu Sosial dan Humaniora: Tantangan dan Perubahan, Fakultas Ilmu Pengetahuan Budaya, Universitas Indonesia, 217-229. https://ppkb.fib.ui.ac.id/seminar-nasionalbudaya-urban/
Rukmana, E N., \& Komariah, N,. (2017). Strategi pemasaran informasi toko buku (Studi kasus di Toko Buku Jatinangor, Sumedang). Berkala Ilmu Perpustakaan dan Informasi, 13 (2), 131-141

Solomon, M. R., Marshall, G. W., \& Stuart, E. W. (2012). Marketing: real people, real choices. New Jersey: Prentice Hall.

Taniguchi, T., Kawakami, H., \& Katai, O. (2009). Bibliobattle: informal community scheme based on book review session. Proc. 8th Int. Workshop on Social Intelligence Design, 92-98. 


\section{DAFTAR TABEL}

Tabel 1. Informan Penelitian

\begin{tabular}{ccll}
\hline No & Nama (disamarkan) & \multicolumn{1}{c}{ Jabatan } & \multicolumn{1}{c}{ Peran pada kegiatan } \\
\hline 1 & Lina & Staf Perpustakaan & Ketua Pelaksana sekaligus pencetus kegiatan. \\
2 & Sarah & Penerjemah & Presenter (sekaligus pemenang), panitia Bibliobattle kedua. \\
3 & Ari & $\begin{array}{l}\text { Desain Komunikasi } \\
\text { dan Visual }\end{array}$ & Presenter, panitia Bibliobattle kedua \\
& Reska & Pranata Humas & Presenter \\
4 & Tania & Pranata Humas & Presenter \\
\hline
\end{tabular}

Sumber: koding data penulis, 2017

Tabel 2. Jumlah Kunjungan Perpustakaan Tahun 2015 dan 2016

\begin{tabular}{ccccccc}
\hline \multirow{2}{*}{ Bulan } & Karyawan Kemensos & \multicolumn{2}{c}{ Mahasiswa } & \multicolumn{3}{c}{ Umum } \\
\cline { 2 - 6 } & $\mathbf{2 0 1 5}$ & $\mathbf{2 0 1 6}$ & $\mathbf{2 0 1 5}$ & $\mathbf{2 0 1 6}$ & $\mathbf{2 0 1 5}$ & $\mathbf{2 0 1 6}$ \\
\hline Januari & 57 & 85 & 29 & 16 & 5 & 5 \\
Februari & 82 & 110 & 16 & 12 & 7 & 2 \\
Maret & 44 & 79 & 21 & 4 & 6 & 6 \\
April & 47 & 76 & 23 & 34 & 4 & 6 \\
Mei & 36 & 47 & 15 & 13 & 10 & 4 \\
Juni & 43 & 49 & 15 & 5 & 7 & 10 \\
Juli & 43 & 35 & 10 & 3 & 6 & 2 \\
Agustus & 50 & 40 & 9 & 3 & 4 & 0 \\
September & 46 & 21 & 13 & 8 & 2 & 5 \\
Oktober & 32 & 68 & 20 & 19 & 1 & 2 \\
November & 40 & 90 & 15 & 11 & 0 & 3 \\
Desember & 45 & 63 & 20 & 19 & 6 & 0 \\
Jumlah & $\mathbf{5 6 5}$ & $\mathbf{7 6 3}$ & $\mathbf{2 0 5}$ & $\mathbf{1 4 7}$ & $\mathbf{5 8}$ & $\mathbf{4 5}$ \\
\hline
\end{tabular}

Sumber: data kunjungan dari Perpustakaan Kementrian Sosial RI tahun 2015-2016

Tabel 3. Statistik Sirkulasi 2015 dan 2016

\begin{tabular}{ccccc}
\hline \multirow{2}{*}{ Bulan } & \multicolumn{2}{c}{ Peminjaman } & \multicolumn{2}{c}{ Pengembalian } \\
& $\mathbf{2 0 1 5}$ & $\mathbf{2 0 1 6}$ & $\mathbf{2 0 1 5}$ & $\mathbf{2 0 1 6}$ \\
\hline Januari & 10 & 75 & 6 & 29 \\
Februari & 12 & 86 & 7 & 54 \\
Maret & 36 & 74 & 15 & 55 \\
April & 27 & 44 & 27 & 51 \\
Mei & 27 & 22 & 23 & 17 \\
Juni & 8 & 42 & 8 & 32 \\
Juli & 13 & 17 & 15 & 18 \\
Agustus & 8 & 36 & 3 & 17 \\
September & 8 & 14 & 10 & 15 \\
Oktober & 19 & 27 & 10 & 21 \\
November & 14 & 37 & 8 & 23 \\
Desember & 16 & 8 & 7 & 14 \\
Jumlah & $\mathbf{1 9 8}$ & $\mathbf{4 8 2}$ & $\mathbf{1 3 9}$ & $\mathbf{3 4 6}$ \\
\hline
\end{tabular}

Sumber: data sirkulasi dari Perpustakaan Kementrian Sosoal tahun 2015-2016 